TITLE: Tritium Control at the Tritium Systems Test Assembly

AUTHOR(S): Roland A. Jalbert

SUBMITTED TO: Fifth International Congress of

the Internaticnal Radiation Protection Association

Terusalem, Israel

8-14 March 1980

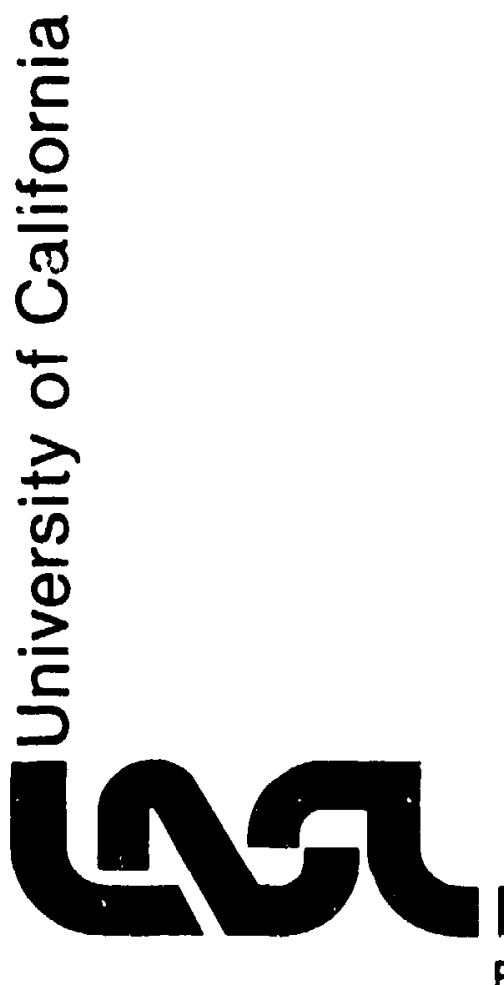

By acceptance of this article, the publisher recognizes that the U.S. Governmmnt retains nonexclusive, royalty-free license to publish or reproduce the published form of this contrisution, Jr to allow others to do so, for U.S. Government purposes.

The Los Alamos Scientific Labaratory requests that the publisher identify this article os work performed under the ouspices of the U.S. Department of Energy. 


\section{TRITIUM CONTROL AT THE TRITIUM SYSTEMS TEST ASSEMBLY*}

\section{Roland A. Jalbert}

University of Califorria, Los Alamos Scientific Laboratory, Los Alamos, NM, U.S.A.

The Tritium Systems Test Assembly (TST:.) is a computercontrolled facility designed to mock up full-scale the deuteriumtritium fuel cycle of next-generation tokamak fusion test reactors. Such reactors will use or build on the experience and technologies of the TSTA and other engineering facilities. The TSTA is presentiy under construction at the Los Alamos Scientific Laboratory and will be fully operational in $i 382$.

\section{DESCRIPTION OF THE FACILITY}

The TSTA will consist of a gas lcop (Fig. 1) and associated control and safety support systems. The loop will include a mock-up torus vacuum chamber followed by cryogenic vacuum and impurity removal systems, a cryogenic hydrogen isotope distillation system, and gas analysis, transfer, mixing and injection systems. The gas loop will be designed to handle a flow of up to $\sim 360$ moles of DT per day. This flow will provide operating experience on a scale that is equal to or greater than that of any of the cycles currently being planned for advanced reactors. To accomplish this will require an on-site tritium inventory of $2150 \mathrm{~g}(1.5 \mathrm{MCi})$.

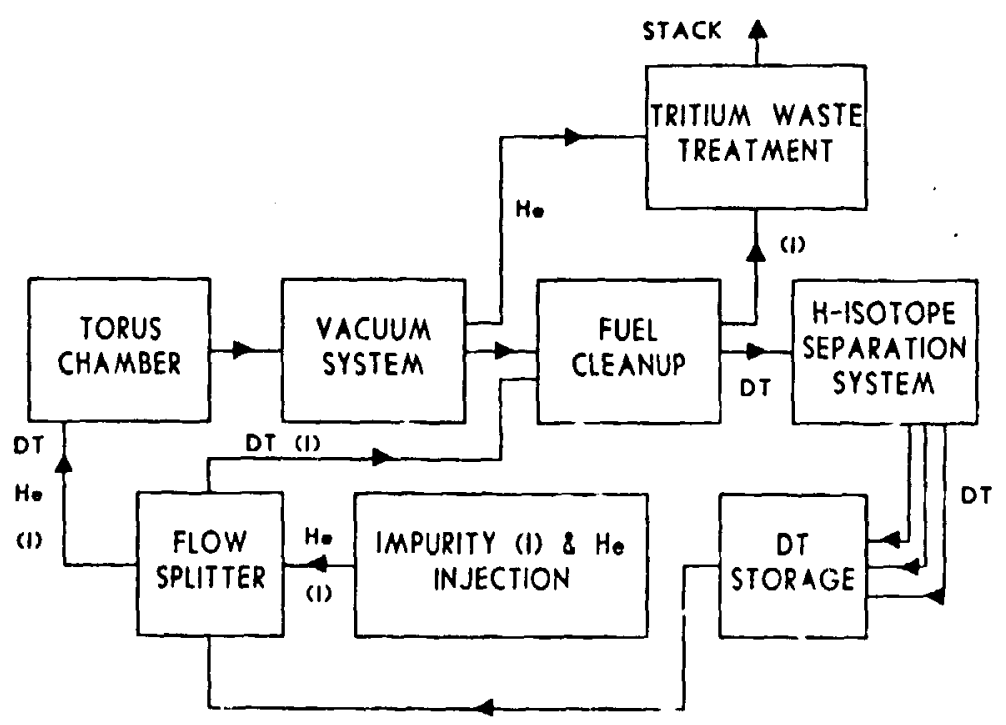

Figure 1. Simplified flow diagram of the TSTA. Note that DT also f:1cludes $\mathrm{D}_{2}$ and $\mathrm{T}_{2}$.

* Work performed under the auspices of the United States Department of Energy.

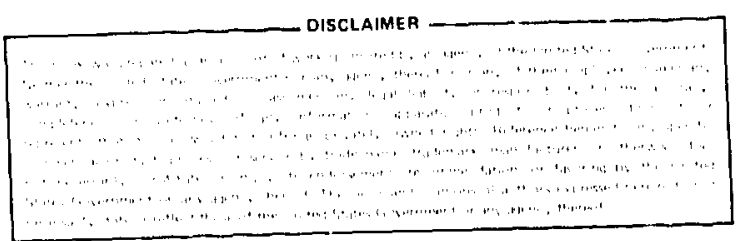


The facility is beirg constructed in an existing steel-frame structure with concrete floor and concrete block walls. The building cqnsists of a large central experimental room (volurne: $\sim 310^{3} \mathrm{~m}^{3}$ ) where the tritium-handling systems will be located, and adjacent areas for the data-acquisition and control computer, mechanical and electrical support equipment, laboratories, shops, anc offices.

The main experimental room and two adjacent laboratories where tritium vill also be handled are on a separate, once-through ventilation system $\left(4 \mathrm{~m}^{3} / \mathrm{s}\right)$ designed to maintain this area at approximately 0.2 torr negative oressure. The exhaust air will be routed to the outside through a $30-m$ stack. The remaining rooms will be maintained at 0.2 torr positive pressure by a separate, partly-recirculating ventilation system. ihe two zones will be connected through air locks which will be maintained at local atmospheric pressure.

An artist's concept of the facility is shown in Fig. 2. Running the length of one side of the main experimental room are two pits $1.5 \mathrm{~m}$ deep. Overhead, about $4.5 \mathrm{~m}$ above the pit floor, are tivo steei mezzanines. With the exception of the torus and vacuum systems, all of the tritium handling components of the fuel loop will be located either on the mezzanines or in the pit areas.

\section{DESLRIPIION OF SAFETY SYSTEMS}

Two of the principal objectives of the TSTA are to demonstrate that the fuel cycle of a large scale fusion reactor incorporating

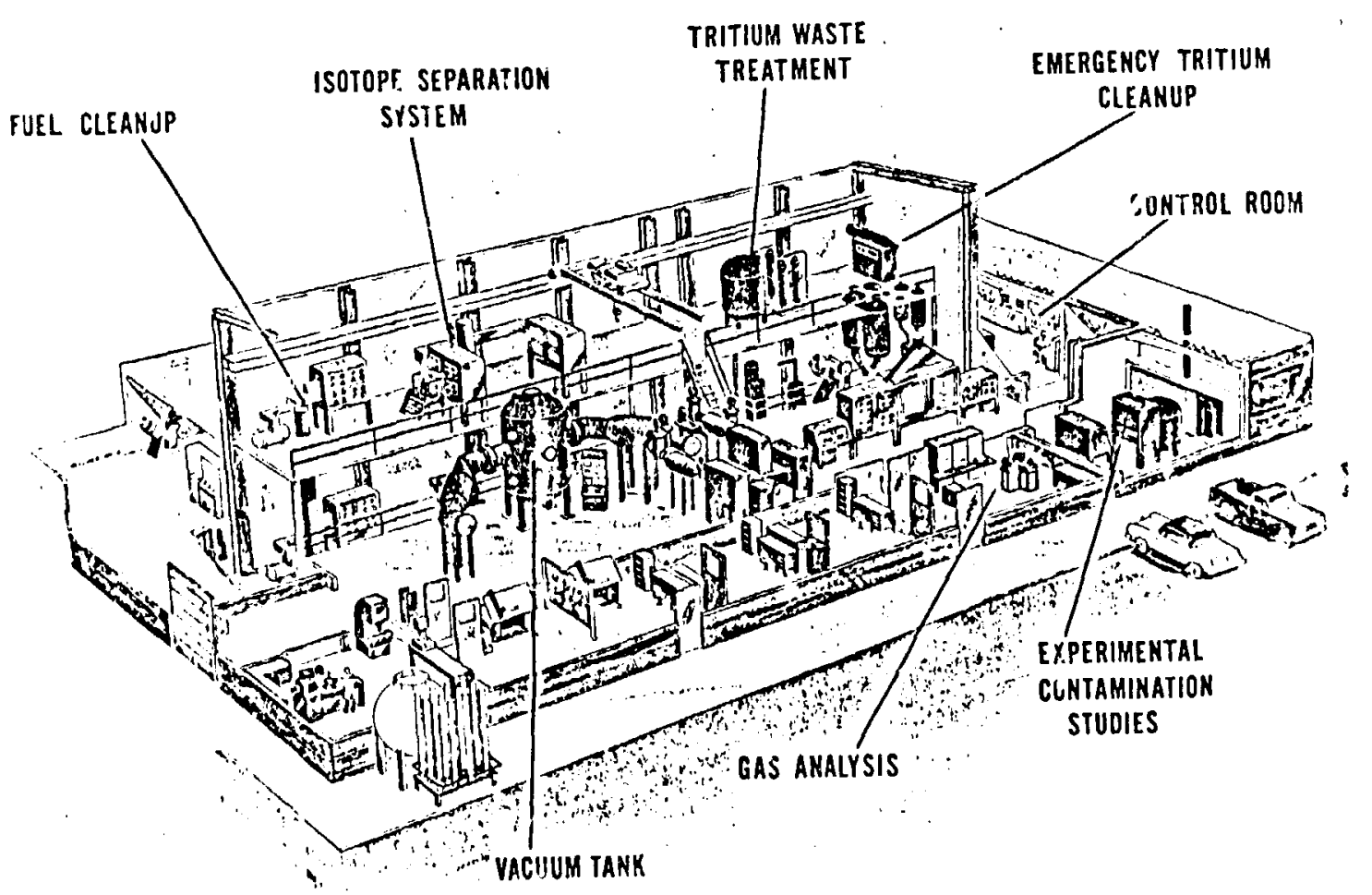

Figure 2. Artist's concapt of the ISTA. 
large quantities of tritiun can be operated reliably and safely. With regard to safe.y, both for workers and the public, two design goals have been set, that of keeping TSTA personnel exposures below $1 \mathrm{rem} / \mathrm{yr}$ and that of maintaining stack ef luents below $200 \mathrm{Cl} / \mathrm{yr}$. These goals are tive result of attempting to reep all potential exposures to tritium "as low as reasonably conievable." To accolplish these objectives, the TSTA will incorporate a number of safety features.

The first of these is multiple containment. All of the system components which may contain tritium will be doubly contained either by inherent design or by being placed in nitrocen-filled gloveboxes. Exceptions inclute the torus chamber, some of the associated vacuum system components, and the tritium cleanup systems. Interconnecting lines transporting tritium between sub-systems will be double-walled with one end of the secondary space open to a glovebox.

The TSTA will have two tritium cleanup systems, an on-line systen, referred to as the Tritium Waste Treatment system (TWT) and in Emergency Tritium Cleanup System (ETC) for processing tritium releases into the main experimental room. Tise TWT is a moderate-size batch-type cleanup system with a maximum processing capacity of $32 \mathrm{l} / \mathrm{s}$. Ruutine tritiated effluents from all of the system components, pumps, etc., as well as releases into glovebcxes can be procesized by this sysiem. It incorporates a large receiving tank $\left(5.7 \mathrm{~m}^{3}\right)$ kept beiow atmosfheric pressure, pre-beater, precious-metal catalyst. bed, compressors, righ pressure receiving tanks, and molecular-sieve beds. The ETC is a $660-\ell / s$ system similar in principle to the TWT but with two main differences: it is a continuous systen (as opposed to a batch system), and is designed so that as munh as $85 \%$ of the moisture in the air may be removed by refrigeration with the remainder removed by molecularsieve beds. The result is that much smaller beds are required for efficient drying of the processed air. The condensed water can be placed on smaller bedz for siipment or disposal or kept as water for recovery of the tritium.

Tritium instruments will help monj.tor the performance on the TWT and the ETC. All but one will be ionizatinn-chamber nonitors with the exception being a scintillation flow-cell monitor in the condensed-water line of the ETC. Gluvebox atmospheres will be monitored with instruments equipped with screen-walled ionization chambers to eliminate the need for air pumps, which are often troublesome. The chambers will be covered with felt which wili serve as crude dust filters. Seven tritium ionization-chamber instruments will monitor the air of the main experimental area with each iristrument monitoring $2-3$ points simultaneously. The ventilation exhaust duct will have its own monitor (with added integrating capability) which will be located about 5 seconds in transient time before the air at the monitor reaches a duct isolation valve. Stack monitoring will be performed by a similar ionization-chamber instrument in addition to a bubbler-catalystbubbler passive integrating system. The condition of each instrument will be routinely monitored by the computer.

A tritium release into a glovebox will be de ected by its monitor, which will be set to alarm at either of two preset levels. The lower-level alarm will plompt only an investigation; with a 
higher-level alarm, the glovebox atmosphere will automatically be flushed to the TWT. If ry one of the room, duct, or stack monitors alarms at its high trip ivel, the ventilation intake and exhaust duct valves will automatically isolate the room. If a second such instrument similarly alarms, the ETC will automatically begin processing the room air.

For a major reiease of $410^{6} \mathrm{Ci}$ of tritium into the room, cleanup of the air is expected to take about $24 \mathrm{hrs}$. Barring any leaks by permeation or through cracks, the total amount released to the environment sholild be under $5 \mathrm{Cl}$.

Experience has shown that at facilities such as the TSTA, the most common tritium exposures result from handling contaminated components during installation, maintenance, or removal of equipment. To minimize this source of exposure, much of the maintenance will be performed either within the gioveboxc 3 where the equipnent is located, or in a special glovebox dedicated to this function. Extensive use will also be made of specially designed flexible plastic enclosures equipped with gloves, and plastic suits supplied with breathing air. To eliminate the amount of tritium that would otherwise be released to the room (and might have to be processed by the ETC), the air within these plastic enclosures will be processed by the TWT or a small transportable scrubber if the level of cortamination warrants it.

To minimize the risk of a significant loss of tritium to the environment should a release to the experimental room occur during a power failure, two supplementary power supplies will be installed: a diesel-powered $750 \mathrm{kVA}$ emergency motor-generator set and an uninterruptable, battery operated, power supply. All tritium moni;ors will be on the battery supply as will be the data acquisition and control computer. In addition to supplying power to the ETC, the emergency generator will provide power to the battery sipply, all pumps, valves, and other equipment necessary for a partial, temporary shutdown of TSTA. All valves and control equipment are designed to "fail safe" and in the event of complete loss of power, the TSTA would shut down in a safe manner.

Chronic releases to the environment will be under $200 \mathrm{Ci} / \mathrm{yr}$. This will result in a maximum dose at the site boundary of less than $1 \mathrm{mrem} / \mathrm{yr}$ and a total local population dose of under $0.2 \mathrm{man}-\mathrm{rem} / \mathrm{yr}$. Major accidental releases to the environment have also been analyzed. One accident scenario that was studied because of the p. Jximity of the facility to the local alrport is an aircraft. accident involving penetration through the roof of the TSTA building. In the scenarlo, the inventoy of the cryogenic isotope separation system $(100 \mathrm{~g})$ is released, oxidized by the accompanying fire and lost to the environment through the roof. With the plure rise from the heated gases, the resultant dose to an exposed person at the site boundary $(0.4 \mathrm{~km}$ distant) is $1 \mathrm{rem}$. An unlikely loss of the entire TSTA inventrry, oxidized and stacked, would result in a dose of less than $5 \mathrm{r}: \mathrm{m}$ at the same boundary point. Releases of this magnitude to the environment as a result of damage caused by natural phenomena (tcrnados, earthquakes) are considered highly unlikely because of the infrequency at Los Alamos of such phonomena of the severity required to cause che necessary damage, and because of the safety features ircorporated into the design of the facility. 